\title{
Service Operations Curriculum Recommendations For Undergraduate Business Majors
}

Elaine J. Labach, Troy University, USA

\begin{abstract}
This article will review the current situation of undergraduate service operations education and will describe the direction that recent educational changes are taking. Given these needs and direction, a proposed curriculum for an undergraduate service operations course is presented. Lastly, a discussion of how undergraduate service operations education needs can be addressed by both industry and academia is included.
\end{abstract}

Keywords: Service, Operations, Curriculum, Business, Undergraduate

\section{INTRODUCTION}

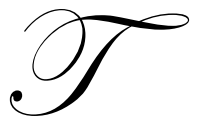

he 2007-08 Recruiting Trends published by Michigan State University cites that hiring of those with undergraduate degrees will be up by $7 \%$ from last year, with $48 \%$ of these recruited degrees being those in business (Collegiate Employment Research Institute, 2008). The service sector continues to drive these employment needs, with jobs in Business Administration/Services, Finance and Insurance, Professional Services and Government up 27\%, 17\%, 9\% and 6\% from last year (Collegiate Employment Research Institute, 2008). The majority of recent undergraduate business school graduates being recruited by service companies or placed in service-providing positions becomes an important trend for those who are concerned with preparing these students for careers in business. While the mission of undergraduate colleges and universities extends beyond preparing students for employability, it is becoming a more important factor as colleges vie for a shrinking undergraduate student population. Colleges that do a better job of preparing their students for business careers will be more competitive in getting these students as undergraduate matriculates.

The Association of American Colleges and Universities (AAC\&U) reports that the gap is widening in terms of preparing undergraduate students for global employment. College students are reported to be underperforming in every academic area, with estimates that less than $10 \%$ of today's graduates have the knowledge and experience to make them globally prepared (AAC\&U, page 8). Confirming this gap, human resource professionals from recruiting businesses cite that less than $25 \%$ of recent college graduates they employ are well-prepared for the workforce (AAC\&U, page 8).

\section{Literature Review}

Business school programs that can prepare their students successfully for a global economy and for the service sector can use this as a differentiation strategy to attract students to their programs. For those faculty in business school programs and who teach operations management, there is an additional challenge. These faculty not only need to prepare students for global positions, but with the necessary knowledge and skills they need to compete in the service sector. And herein lies the biggest gap. When looking at business school curricula across the nation, the majority of undergraduate business schools do not offer undergraduate operations service management courses (Bahl 1989; Fitzsimmons 1999; Davis and Berdrow, 2008). 
While four out of the top ten MBA business schools offer service management programs (Davis et al, 2008), a disportionately few service management programs exist at US business schools (either at the graduate or undergraduate level). Of the existing programs, about half are not integrated directly into the curricula, but are rather separate industry/academic centers or associations that serve the business school or university (Davis et al, 2008).

\section{Service Vs. Manufacturing Operations}

Many business school programs continue to offer traditional operations management curricula, and these fall short of providing the necessary preparation to students who will more than likely start their careers in the service sector. The knowledge and skills needed for service operations are different from traditional operations management curricula that focus on manufacturing, or production, operations. The major differences are (taken from Davis et al, 2008, page 31).

1. Customer Interaction - the customer is a direct part of the product, process and outcome. In traditional manufacturing operations management, the product is not the customer, but a separate, tangible entity.

2. Intangibility - services cannot be touched, but are the "act" of being performed. In traditional operations management, the product is a tangible, deliverable entity.

3. Perishability - in traditional operations management, inventory of products is an important and useful topic. However, is very difficult to inventory customers, as un-served customers cannot be stored for later use. This makes it extremely important to closely match capacity to expected customer demand, and this becomes a very important topic in service operations management.

4. Performance Measures - measures that apply specifically to service businesses are different from traditional operations, and include:

a. Tangibles (appearance of facilities, etc.)

b. Reliability (accurate and dependable service delivery)

c. Responsiveness (prompt service)

d. Assurance (convey knowledge, trust and confidence)

e. Empathy (caring, concern and attention)

One factor that must be taken into consideration when preparing students for service operations is the content, or topics, to place in the curricula for a service operations management course. These should focus on the nature of service delivery.

\section{Support Services Integrated}

Another aspect of service operations that is different from a traditional operations management focus is how the internal functions are organized. Figure 1 shows a traditional value chain (Porter, 1998), where production operations are supported in a chain by logistics, marketing, sales and service. Organizational areas of support include Technology Development (Information Technologies), Human Resources, General Administration (i.e., Finance/Accounting) and Procurement.

Figure 2 shows a Service Profit Chain (Heskett, Jones, Loveman, Sasser, Schlesinger 1994) superimposed on a traditional value chain. The operations block is oriented toward creating value to customers by maintaining loyal, satisfied and productive employees. To accomplish this, general administration and support services (such as Information Technologies, Human Resources, Facilities, etc.) are integrated directly in the operations function to create and maintain an environment where employees of a service delivery firm can meet and exceed customer expectations. The way support services are integrated is another key factor that makes service operations different from traditional operations management. 


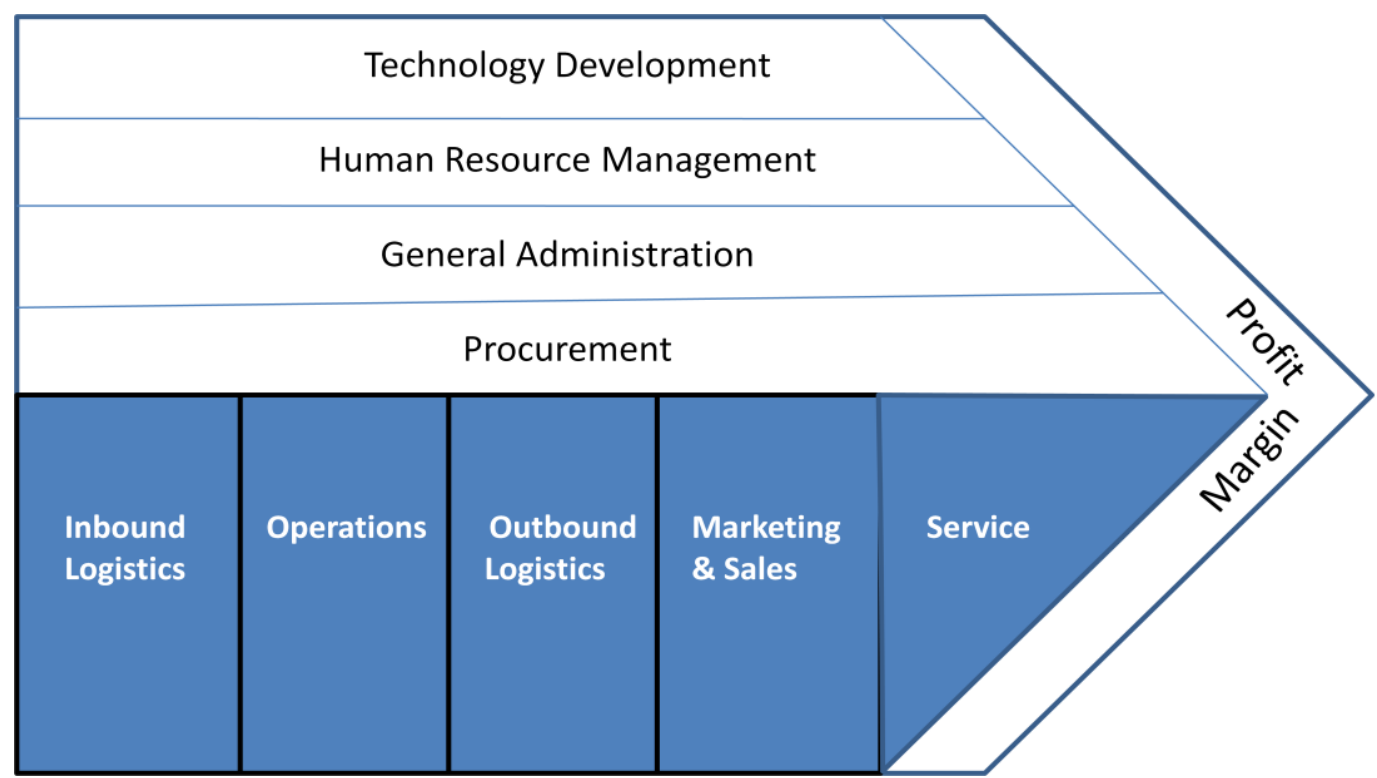

Figure 1: Traditional Value Chain

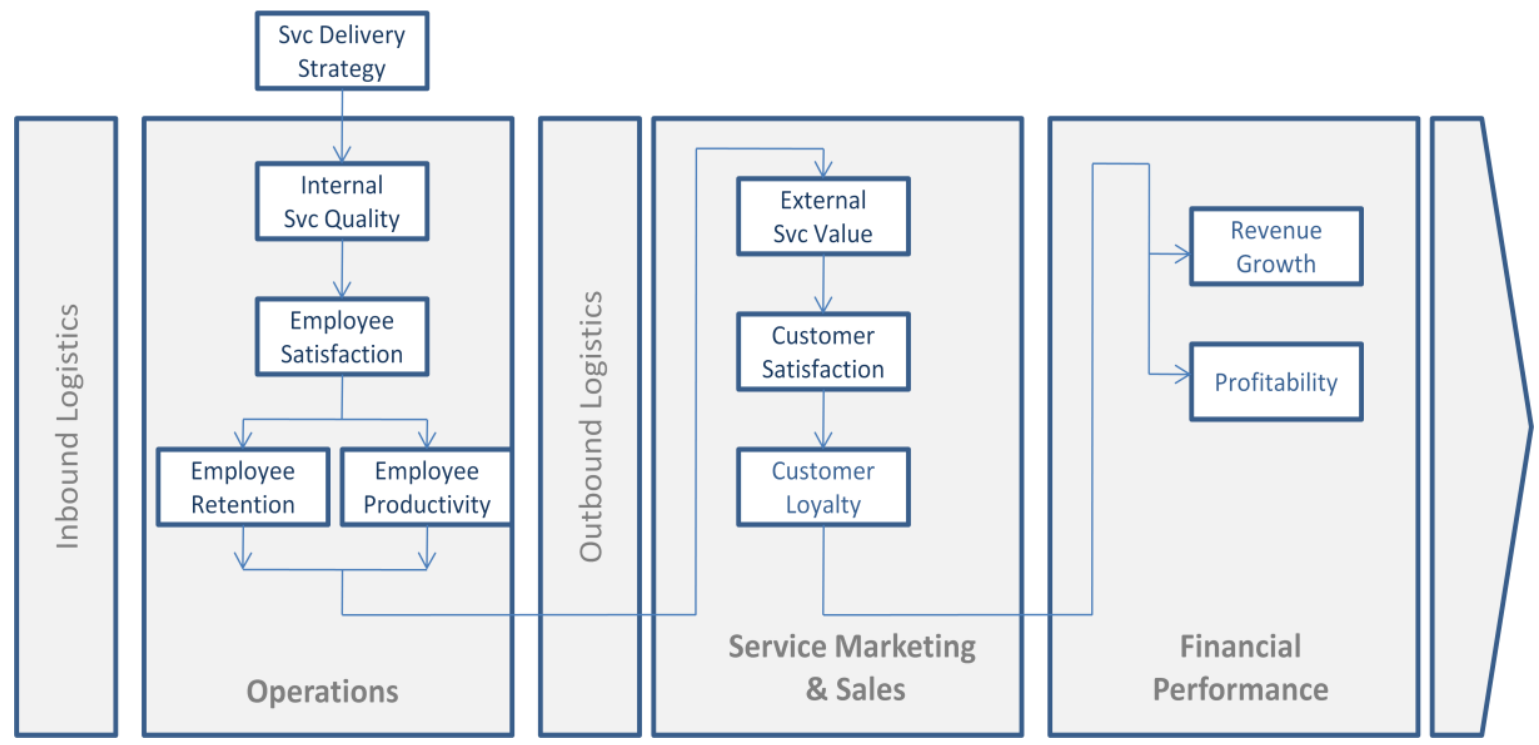

Figure 2: Service Profit Chain Superimposed on Traditional Value Chain

\section{Cross-Functionality With Marketing And Finance}

Another key factor in service operations is the strong interface with both the marketing and finance functions, both of which drive performance. The concept of the service profit chain tells us that when services are delivered, value is created and customer satisfaction and loyalty are stimulated. When service delivery succeeds, the quality and quantity of market share is enhanced, which leads to revenue growth and profitability. For example, a $5 \%$ increase in loyalty can result is a $25-85 \%$ increase in profitability (Heskett et al, 1994). Taking a traditional operations management perspective, direct costs of labor and materials are tied directly to financial performance. Market performance is not directly correlated. In a service delivery operations environment, a strong correlation 
exists that tie service performance measures to the financial and market performance of the firm.

\section{SERVICE OPERATIONS CURRICULUM}

\section{Modeling Framework}

One approach to developing a service operations course is shown in Figure 3, where the curriculum incorporates current and future academic and industry needs, along with course content and teaching pedagogy. By including strong ties to industry, the curriculum can be re-aligned to serve academic, industry and student needs. For example, by aligning to industry, graduates will have more employable skills and industry will have access to better prepared graduates. Academic needs can be fulfilled as well by focusing on knowledge and key skills it deems important. Pedagogy can be a key bridge between course content, academic goals and industry needs. For example, pedagogies that focus on critical thinking and problem-based learning are transferable (i.e., deemed professional as well as life skills).

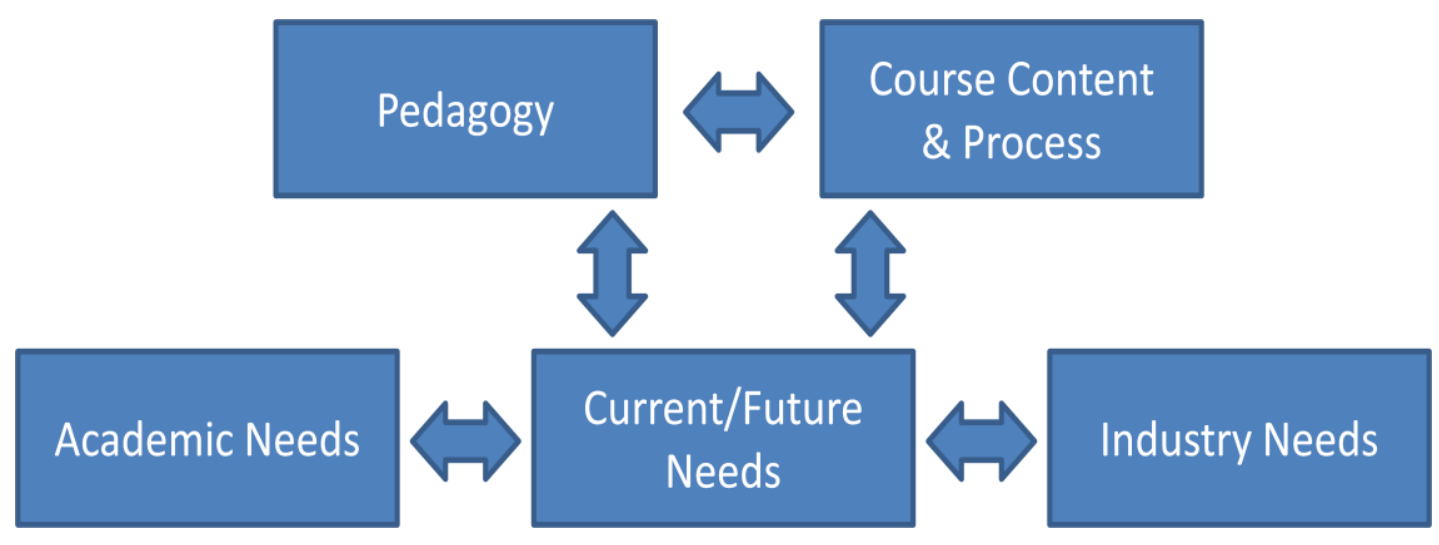

Figure 3: Service Operations Curriculum Modeling Framework

What is known in the literature about understanding these various blocks leaves plenty of room for further research. The most well-known block is the course content block. The least well known blocks are the process (i.e., course delivery) and teaching pedagogies. It is generally accepted that undergraduate service operations should primarily focus on core service management topics, although some integration between disciplines is recommended, with more integration at the MBA level (Davis et al, 2008).

There have also been studies that show problem-based learning (i.e., case studies) can be used to develop critical thinking skills in a business curricula (Braun, 2004). Simulations can also be a useful approach to apply problem-solving skills in operations management (Green et al, 2000). More research should be done to identify key delivery strategies and teaching pedagogies that reinforce undergraduate service operations learning outcomes.

\section{DIRECTION OF SERVICE OPERATIONS}

\section{Core Curriculum}

By looking further into the Service Profit Chain, we can use this to identify the important elements and linkages needed for service operations. For example, internal service quality and external service value can be broken down into the following topics:

Internal Service Quality:

- $\quad$ Process analysis (work place design)

- $\quad$ Managing capacity and demand 
- $\quad$ Service quality management

- $\quad$ Service productivity improvement

- $\quad$ New service development

External Service Value:

- $\quad$ Managing the service encounter

- $\quad$ Managing customer queues

- $\quad$ Service recovery (improving customer satisfaction/loyalty after a poor encounter)

- $\quad$ Service delivery and profitability performance measures

By reviewing these topics, it is clear that different types of knowledge are required for service operations as compared to traditional operations management. Not only is there more of an emphasis on the importance of soft skills in the delivery of services, but also more complexity in problem solving. If the substance, or content, different, the also delivery needs to consider how to induce students to appreciate these and apply in a service setting. A need for more critical and integrative thinking is required to understand these nuances of a service operations function.

Given that a list of topics is fairly straightforward, the next consideration is the availability of teaching materials and cross-disciplinary support. Based on the author's development of a service operations course, the following gaps in Table 1 shows what exists and needs development in terms of service operations course content. Cases are the preferred pedagogy to support problem solving and critical thinking, while cross-disciplinary coverage is the strategy used to provide the integrative perspective.

Table 1: Service Operations Management Resources

\begin{tabular}{|l|c|c|}
\hline \multicolumn{1}{|c|}{ Service Operations Topic } & Cases Available? & Interdisciplinary Coverage? \\
\hline Process Analysis & Yes & \\
\hline Managing Capacity/Demand & Yes & Marketing \\
\hline Service Quality Mgmt & Yes & Human Resources, IT \\
\hline Service Productivity Improvement & Yes & Marketing/Finance \\
\hline New Service Development & No & Marketing \\
\hline Managing the Service Encounter & Limited & Marketing/Finance \\
\hline Managing Customer Queues & Limited & No \\
\hline Service Marketing/Recovery & Limited & \\
\hline Service Delivery Outcomes & & \\
\hline
\end{tabular}

\section{Integrative Skills Sets}

The Service Profit Chain also indicates that elements and links in the chain impact performance. For example, in order to affect internal service quality, attention must be paid to enhancing the service providers' environment and satisfaction. This can involve various support functions such as Information Technologies (IT), Human Resources (HR), Facilities and Finance. For example, if a call center wants to improve its customer service satisfaction, it must ensure that its personnel are trained and incentivized (HR) and that they have the tools and environment needed for responsive and caring service (IT and Facilities). A mechanism must be used to track customer retention and increased market share and sales (IT). Thus, a more integrative perspective is needed to understand how to impact and sustain positive change in a service business.

As previously mentioned, case studies have been shown to induce students to take a more integrative approach as well as to understand the importance of "soft" skills in service delivery. One way to compensate for a lack of teaching cases is to team-teach topics that cross disciplines. For example, disciplines in IT and HR can be combined to discuss opportunities and challenges in service productivity improvement. Another way to take a more integrative approach is to incorporate guest speakers, simulations, projects or internships - any increase in the interaction of the various disciplines in a service business would offer some value as students see the bigger picture. 


\section{Performance Measure Linkages}

A final lesson of the Service Profit Chain is it defines and correlates measures of service operations performance to market and financial success. For example, how does employee satisfaction and retention relate to customer satisfaction, market share and profitability? Service operations professionals must understand how service delivery impacts the performance of the service firm. This implies more cross-functional and disciplinary learning and application.

One way that academic institutions have encouraged cross-disciplinary learning is through the use of integrative case studies that cross disciplines. For example, Indiana University's School of Business uses an integrative case in the last weeks of their undergraduate marketing, operations and finance classes. Another way to show how service elements impact financial score cards is to use teaching simulations. For example, Harvard Business School Publishing offers a Benihana restaurant simulation that allows students to simulate how restaurant design and customer management impacts restaurant profitability.

\section{Alignment with Academic Institutions}

Although generating core topics recommended for an undergraduate service operations curriculum can be easily done, there is no "one-size-fits-all" recommendation. Any undertakings in building a service operations course should be reinforced with other programs of study that the academic institution offers. For example, if the undergraduate program offers a capstone course where there is synthesis across specialized business areas, this can be reinforced to build student teamwork, problem solving and critical thinking skills. Another aspect of service operations is to integrate it with student work experience, or internships offered in service settings.

As Table 1 illustrated, service operations cases and instructional materials may be limited. This requires curricular leadership from scholars and teachers, along with support from the college leadership.

Inviting employers in for class discussions, and putting them in direct dialogue with students, will not only will provide a stronger emphasis on the knowledge and skills sets needed, but will help students see that completing their undergraduate studies is just the beginning of what they will need to be successful in a service operations career.

\section{Alignment with Industry}

Industry is currently addressing the skill gap of their employees with cross-training, job rotation, crossfunctional teams, partnerships with academia, and attendance to internal/external professional development programs. Specifying current/future needs of industry could help define where both business school programs and undergraduate service management courses could be of the most value.

\section{CONCLUSION}

Although some progress is being made to close the gaps on what undergraduate students need to be successful in service careers, we need to increase the rate at which we develop curricula that meet academic, industry and student needs. Academic institutions will be pressured to compete for fewer undergraduate students, which should help drive some of the programs needed. Faculty will need not only college leadership commitment, but also support from industry. This support can come in the form of partnerships to identify current/future needs and to co-develop educational materials. Additional research is needed to identify specific programs and courses that other undergraduate business schools offer, whether or not these courses are provided with an interdisciplinary approach and associated student learning outcomes. Additional research is also needed to identify best practices in course curriculum and pedagogies. The service sector and its associated growth in jobs is here to stay, and programs that deliver the necessary skills and experiences to help students be successful will ensure these academic programs are successful in the long term. 


\section{AUTHOR INFORMATION}

Elaine Labach: Shortly after graduating with a BS in chemical engineering, Elaine Labach began her career in an automotive manufacturing facility. She then attended graduate school and received her MBA from the University of Michigan and $\mathrm{PhD}$ from Indiana University. Elaine has held positions in both academia and management, with business experience primarily in the service sector. She is currently an Assistant Professor with Troy University.

\section{REFERENCES}

1. Bahl, H. (1989). Teaching Production and Operations Management at the MBA Level - A Survey. Production and Inventory Management Journal, 30, 5-8.

2. Braun, N. (2004). Critical Thinking in the Business Curriculum. Journal of Education for Business, March/April, 232-236.

3. Brody, R., Coulter, J. (2002). Preparing Business School Graduates for the $21^{\text {st }}$ Century Workplace. College Student Journal, 36, 222-234.

4. College Learning for the New Global Century: Liberal Education \& America's Promise (2007). Association of American Colleges and Universities: Washington, DC.

5. Collegiate Employment Research Institute Annual Review (2008). Michigan State University. Retrieved 11/30/08 from http://.ceri.msu.edu/publications/pdf/finalrt7-8.pdf

6. Davis, M., Berdrow, I. (2008). Service Science: Catalyst for Change in Business School Curricula. IBM Systems Journal, 47, 29-38.

7. Fitzsimmons, J. (1999). Curriculum and Research in Service Operations Management. Production Operations Management, December/January, 8-10.

8. Green, F., Williamson, J. (2000). Creating a College and Business Partnership that Works: Simulation in a Manufacturing Environment. Journal of Education for Business, 75, 164-169.

9. Heskett, J., Jones, T., Loveman, G., Sasser Jr., E., Schlesinger, L. (1994). Putting the Service-Profit Chain to Work. Harvard Business Review, March-April, 164-174.

10. Junghagen, S. (2005). Working with Business and Industry to Enhance Curriculum Development and Student Employability. New Directions for Institutional Research, 128, 69-81.

11. Porter, Michael (1998). Competitive Advantage: Creating and Sustaining Superior Performance. New York, NY: Free Press.

12. Tanyel, F., Mitchell, M. (1999). The Skill Set for Success of New Business School Graduates. Journal of Education for Business, 75, 33-38. 
NOTES 